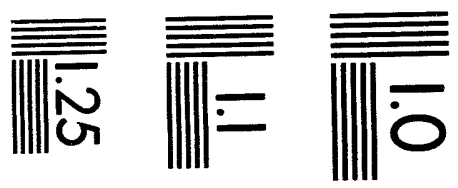

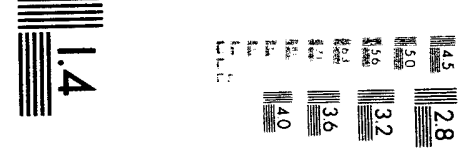

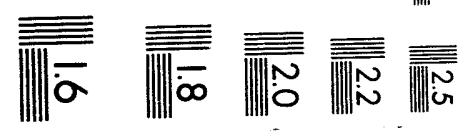



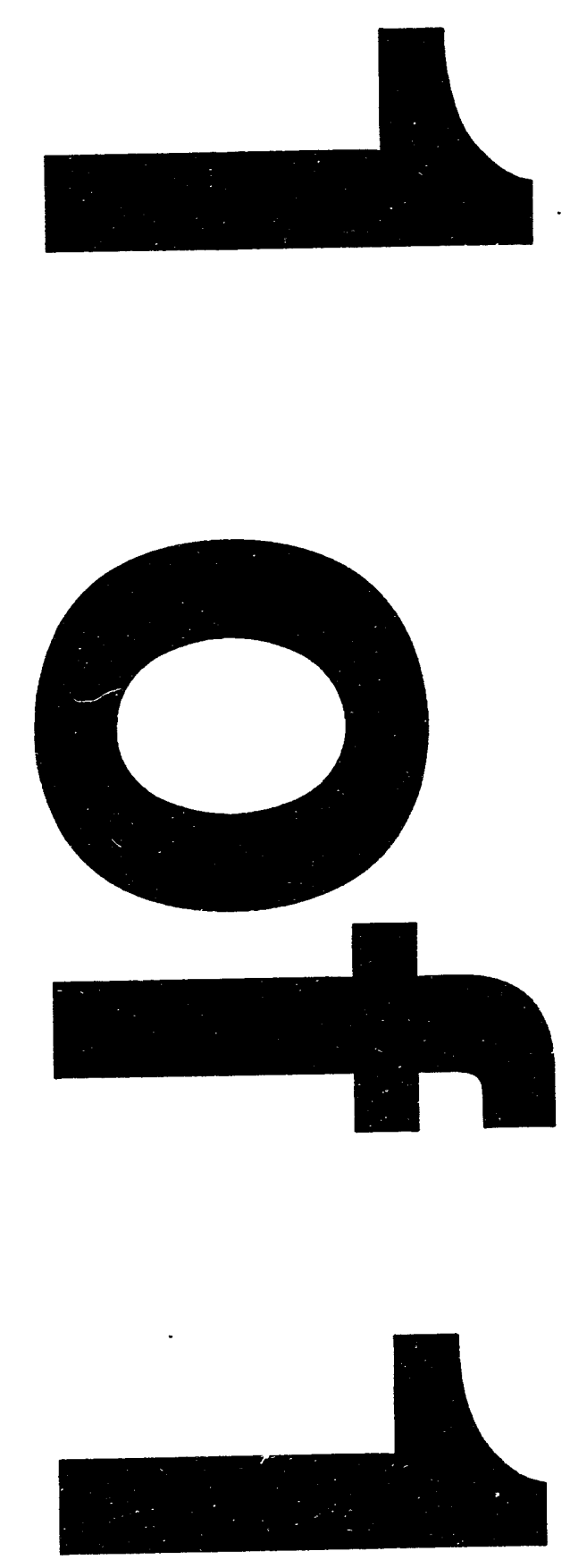


\title{
Status of Waste Isolation Pilot Plant Compliance with 40 CFR 191/, December 1992
}

\author{
M.G. Marietta and D.R. Anderson \\ WIPP Performance Assessment Department 6342 \\ Sandia National Laboratories \\ Albuquerque, NM 87185
}

\begin{abstract}
Before disposing of transuranic radioactive waste at the Waste Isolation Pilot Plant (WIPP), the U.S. Department of Energy (DOE) must evaluate compliance with long-term regulations of the U.S. Environmental Protection Agency (EPA). Sandia National Laboratories (SNL) is conducting iterative performance assessments (PAs) of the WIPP for the DOE to provide interim guidance while preparing for final compliance evaluations. This paper describes the 1992 preliminary comparison with Subpart B of the Environmental Standards for the Management and Disposal of Spent Nuclear Fuel, High-Level and Transuranic Radioactive Wastes (40 CFR 191), which regulates long-term releases of radioactive waste. Results of the 1992 PA are preliminary, and cannot be used to determine compliance or noncompliance with EPA regulations because portions of the modeling system and data base are incomplete. Results are consistent, however, with those of previous iterations of PA, and the SNL WIPP PA Department has high confidence that compliance with 40 CFR $191 \mathrm{~B}$ can be demonstrated. Comparison of predicted radiation doses from the disposal system also gives high confidence that the disposal system is safe for long-term isolation.
\end{abstract}

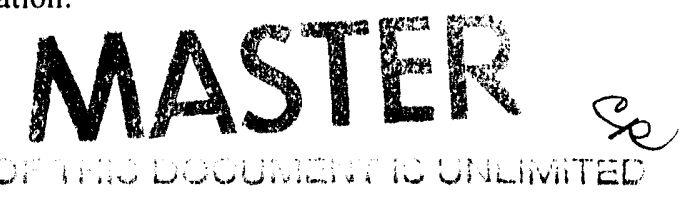




\section{ACKNOWLEDGMENTS}

The authors wish to recognize the technical reviews of this report by David Gallegos and Andrew Peterson (6342) of Sandia National Laboratories. 


\section{PREFACE}

This SAND report is a reproduction of the identically titled paper published in:

American Nuclear Society and American Society of Civil Engineers. High-Level Waste Management:

Proceedings of the Fourth Annual International Conference in Las Vegas, NV, April 26 - 30, 1993. American Nuclear Society, La Grange, IL; American Society of Civil Engineers, New York, NY. 
STATUS OF HIPP COMPLIANCE HITH EPA 40 CFR 191B

DECEABER 1992

M.G. Mariette and D.R. Anderson

WIPP Performance Assessment Department 6342

Sandia National Laboratories

Albuquerque, New Mexico 87185

(505) 844838

\begin{abstract}
Before disposing of transuranic radioactive waste at the Waste Isolation PIlot Plant (WIPP), the United States Department of Energy (DOE) aust evaluate compliance with long-term regulations of the United States Environmental Protection Agency (EPA). Sandia National Laboratories (SNL) is conducting iterative performance assessments (PAs) of the WIPP for the DOE to provide interim guldance while preparing for final compliance evaluations. This paper describes the 1992 preliminary comparison with Subpart B of the Environmental standards for the Management and bisposel of spant Nuclear Fuel, High-Lovel and Transuranic Radioactive Wastes ( $40 \mathrm{CFR}$ 191), which regulates long-term releases of radioactive waste. Results of the 1992 PA are preliminary, and cannot be used to determine compliance or noncompliance with EPA regulations because portions of the modeling system and data base are incomplete. Results are consistent, however, with those of previous terations of $P A$, and the SNL WIPP PA Department has high confidence that compliance with $40 \mathrm{CFR} 191 \mathrm{~B}$ can be demonstrated. Comparison of predicted radiation doses from the disposal system also gives high confidence that the disposal system is safe for long-term isolation.
\end{abstract}

\section{INTRODUCIION}

The United States Departwent of Energy (DOE) 1s developing the Waste Isolation P1lot Plant (VIPP), located in 255 million-year-old bedded salt in southeastern New Mexico, for disposal of transuranic wastes generated by defense programs. The DOE must first evaluate compliance with the Environmental Protection Agency's (EPA) Environmental standarda for the Menagement and Disposal of spent Wuclear Fuel, Migh-Level and Transuranic Radionctive Wantos (40 CFR Part 191), 1 and with the zand bisposal Restriction. ( 40 CFR Part 268) ${ }^{2}$ of the besardous and Solid waste imendments to the kesource Conervation and Recovery Act. The Mational Environmental Policy ACt (NEPA) ${ }^{3}$ requires all agencies of the federal government to prepare a detalled etatement on the onvironental lupacts of "proposed major federal actions affecting the quality of the human enviroment." In compllance with the NEPA, an additional supplenental environental lepact statement (SEIS) is planned prior to peranent disposal.4 This paper addresses the present status of WIPP coapliance with Subpart B of 40 CFR 191 and an evaluation of long-tern safety of the WIPP.

Subpart B of 40 CFR 191 was vacated by a Federal Court of Appeals in 1987 and is undergolng revision; by agreement with the State of New Mexico5 the DOE will continue to evaluate repository performance with respect to the standard as first pronulgated until a neh version is avallable. The weate Isolation Pilot plant Land withdrawal Act, 6 which mandates specific actions before the Test Phase for the WIPP can begin, requires the EPA to repromulgate the regulation before May 1993. The approach to $40 \mathrm{CFR} 191 \mathrm{~B}$ and the resultant wethodology reported here have not been modified to reflect the EPA' efforts to develop new Subpart B. The Contalnnent Requiresents in Subpart $B$ of $40 \mathrm{CFR} 191$ set limits on the probability that cumulative radionuclide releases to the eccessible environment during the 10,000 years following decomissioning of the repository will exceed certain linits. As defined in the standard, the accessible enviroment is " (1) the atmoshere; (2) land surfaces; (3) surface vaters: (4) oceans; and (5) all of the 11thosphere that is beyond the controlled area" $(191.12[k]) .1$

To comply with the requirements of 40 CFR 191B, performance assessments (PAs) must construct a vodeling system that can adequately - imulate all realistic future states of the repository that alght result in radionuclide releases. Because the regulatory liaits are probabilistic, PAs must accurately reflect variabllity and uncertainty within all factors thet contribute to the imulation, including 
varlabllity in materlal properties, probabilities of future human actions, and uncertainties inherent in the conceptual and numerical nodels that simulate reality. In keep1ng with the strategy of the WIPP Project Headquarters for achleving a compliance decision, 4 the WIPP PA Departaent has completed three annual PAs evaluating prelininary compliance with $40 \mathrm{CFR}$ Part 191 , Subpart B. 7-16

This paper sumarizes the present status of UIPP PA.14-16 All PA results to date are prelininary and cannot be used to determine coapliance or noncompliance with EPA regulations governing long-term performance. Only the longterm performance of the disposal system is addressed.

\section{IKADVERTENT HUMAN INTRUSION}

PAs for 40 CFR 191B presently concentrate on inadvertent human intrusion during exploratory drilling for resources, which has been demonstrated by past analyses 17,18,10-12,19 to be the only event likely to lead to radionuclide releases close to or in excess of regulatory limits. Future drilling technology is assumed for these analyses to be comparable to technology presently in use in the region around the WIPP.

If the waste-disposal panels are penetrated by an exploratory borehole, radionuclides way reach the accessible environment by two principal pathways. First, some radionuclides will be transported up the borehole directly to the ground surface. Second, additional radionuclides transported up the borehole will migrate into overlying strata and may be transported laterally in groundwater to the subsurface boundary of the accessible environment.

Most releases at the ground surface will be in the form of particulate waste entrained in the drilling fluid, including components from cuttings (material removed by the drill bit), cavings (material aroded from the borehol wall by the circulating drilling fluld), and spallings (material that enters the borehole as the repository depressurizes). For conventence, these particulate releases are collectively referred tn in perfornance-assessment documentation as cuttings. For the 1992 calculations, results referred to an cuttings include cavings but do not include spallings. If important, spallings will be included in future PAs when models and data are available. Release of radionuclides dissolved in brine that way flow up the borehole to the ground surface both during drilling and after degradation of plugs has not been included either in past PAs or in the results presented in this volume. Preliminary analyses of releases by these mechanisms will be included in later PAs.
Subsurface releases of radionuclides following lateral transport in groundwater are belleved nost likely to occur in the Culebra Dolonite Moaber of the Rustler Formation overlying the repository. For analysis purposes, subsurface transport is assuned to occur only in the Culobra, aximizing the potential for releases by this pathway.

Figure 1 illuetrates a representative Intrusion scenario. In the scenario, borehole penetrates the repository and hypothetical pressurized brine reaervolr in the underlying Castlle Formation.

\section{COMPUTATIONAL MODELS}

The primary couputer prograns used in the computational models for the 1992 preliminary PA (F1gure 2) reflect iaprovenents in the conceptual and nunerlcal nodels used in the 1991 and previous PAs and permit the replacement of simplifying assumptions with nore realistic nodel.. Three of the nost slgnificant improvenents in 1992 are discussed here.

The 1992 calculations aark the first time the effects of salt creep have been explicitly included in PAs. Salt will deform over time by creep in response to a pressure gradient, and, If the repository remalned at atnospheric pressure, lithostatic stresses would cause 1 to close almost completely within 100 years. 20-22 Gas will be generaced within the repository by degradation of the waste, however, and pressure within the repository will rise to elevated levels that will retard complete creep closure and ay perhaps partially reverse the process. In 1991 no nodel was avallable to describe the coupled interaction of creep closure and gas pressurization, and the perforance-assessment calculations used a saplifylng assumption that porosity withit the diaposal region vould remain constant through time. The 1992 calculations use cutput from the geonechanical code SANCHO23 to define the porosity of the waste as a function of pressure. Although this nethod does not represent a full coupling of creep closure and gas gensration, the modeling improvenent allows the PA to evaluate the laportance of changing vold volume in the repository.

The method used to incorporate spetiel variability in the transalseivity field in the Culebra has been modified significantly from that used in 1991. WIPP PA now uses an automated Inverse approach to calibrate a twodimensional model to both stady-state and translent pressure data, geilerating multiple reallzations of the transaissivity field. 15,24 Seventy callbrated fleids were sampled for use In the $1992 \mathrm{PA}$.

Radionuclide transport in the Culebra Dolomite, which had been simulated using 


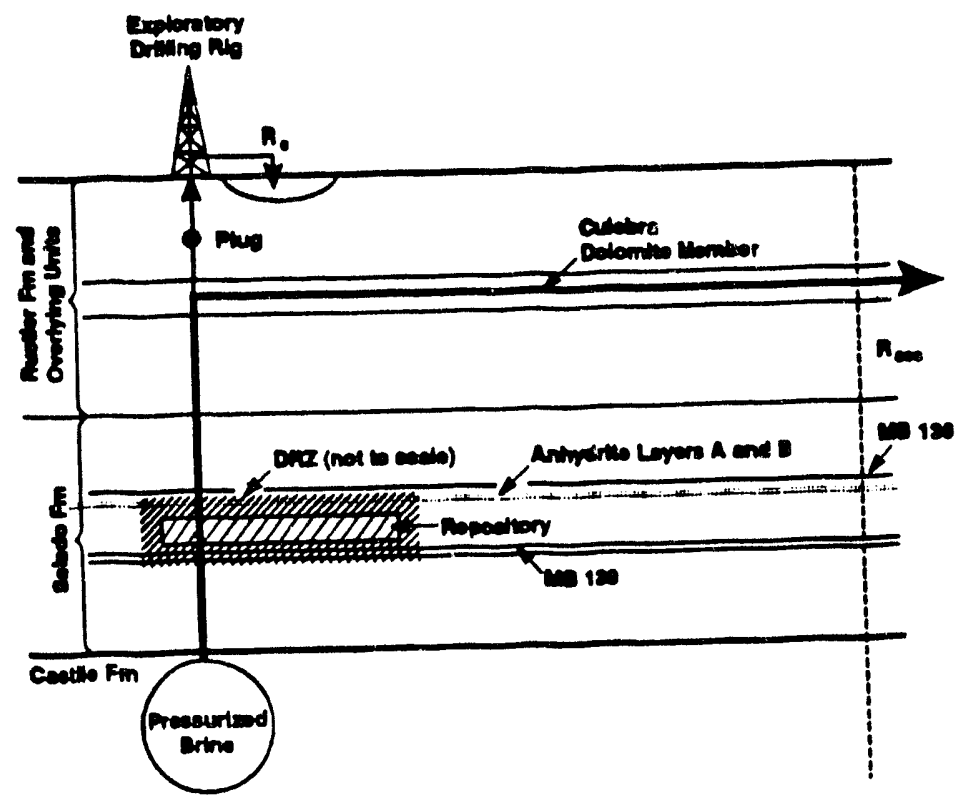

momants

Figure 1 - Conceptual model for an intrusion scenario in which a borehole penetrates the repository and a hypothetical preseurlzed brine reservolr in the underlying Castile Formation. Arrows indicate assumed direction and relative agnitude of flow. $R_{c}$ is the release of cuttings and eroded material. $R_{a c c}$ is the release the subsurface boundary of the accessible environment. Illustrated plugs are assumed to remain intact for 10,000 years.

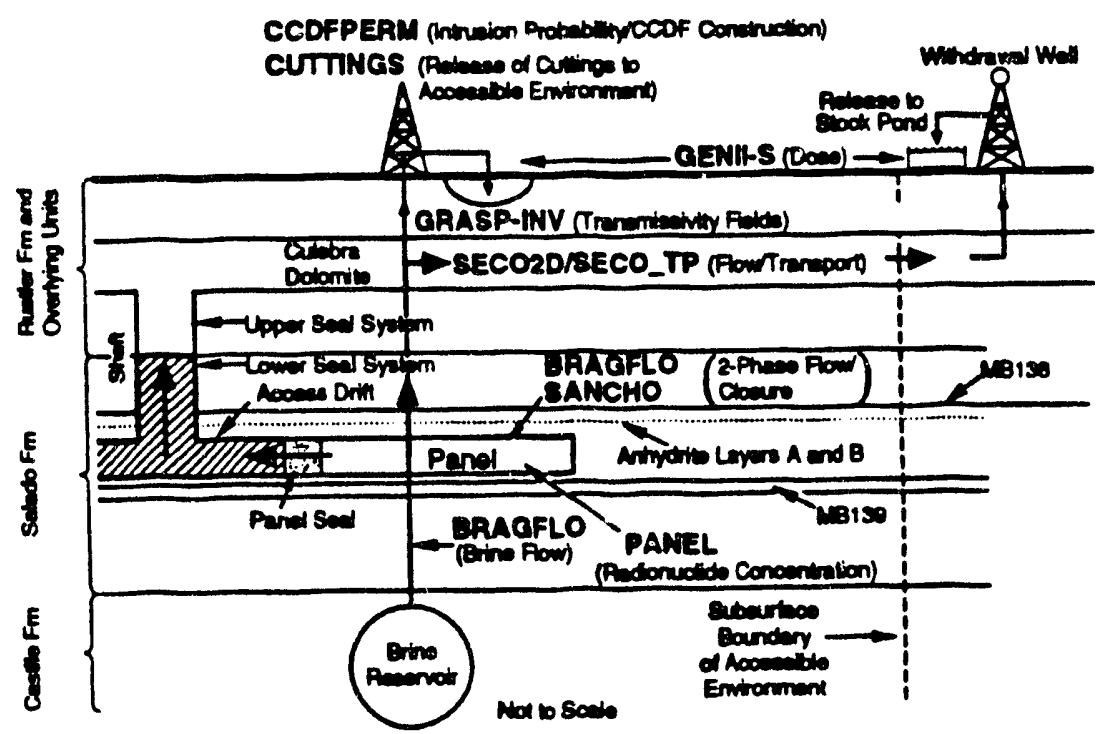

noperserto

Figure 2 . Major codes uned in the 1992 performance essessment. 
STAFF2D25 in the $1991 \mathrm{PA}$, is now sluulated by the SECO-TP code. 16 SECO-TP is a dual-porosity model in which advective transport is allowed only in fractures, and diffusion of solute occurs into the rock matrix surrounding the fracture. The fracture system is idealized as planar and parallel, and each fracture wall may be coated with a layer of clay of uniform thickness and porosity. The model is capable of simulating both physical retardation by diffusion and chemical retardation by sorption in both clay fracture linings and dolomite matrix.

\section{PROBABILITIES OF SCENARIOS}

Preliminary PAs for the WIPP prior to 1990 considered a fixed number of human intrusions with fixed and arbitrary probabilities.17,26 The 1990 preliminary assessment ${ }^{7}$ compared performance assuming fixed probabilities for intrusion events with performance estimated assuming that intrusion through the repository follows a Poisson process (1.e., intrusion events are random in time and space) with a rate constant, $\lambda_{0}$. The 1991 assessment 10,11 included a probability model based on the poisson assumption and also included effects of variable activity loading within the waste-disposal panels with boreholes intersecting waste of five different levels of radioactivity. 13 Based on guidance in Appendix $B$ of $40 \mathrm{CFR} 191$, a maximum of 30 boreholes $/ \mathrm{km}^{2}$ were allowed in 10,000 years.

The 1992 preliminary PA marks the first use for the WIPP of external expert fudgment to estimate the probability of future intrusion. Teams of experts from outside the WIPP Project were selected and organized into two panels to address (1) the nature of future societies and the possible modes of intrusion, and (2) types of markers and their potential effectiveness in deterring intrusion. 16 The judgments elicited from these panels were used to construct an algorithm describing possible changes in the Poisson rate constant, $\lambda_{t}$, with time. 16 The 1992 preliminary PA presents results calculated both using the 1991 time-invariant formulation and the time-dependent formulation based on external expert judgment. Both formulations used the same representation for variable activity loading within the waste-disposal panels used in the 1991 PA. 13 The time-dependent formulation, which included the deterrence effect of markers, resulted in significantly fewer intrusions than the time-invariant formulation.

\section{RESUL'S OF THE 1992 PERFORMANCE ASSESSMENT}

Results of the 1992 PA are consistent with the conclusion made in previous preliminary comparisons that performance estimates for the WIPP lie below the limits set by the Containment Requirements of Subpart B of 40 CFR 191.7,10 As illustrated in Figure 3, consideration of alternative models for the probability of human intrusion and radionuclide transport in the Culebra Dolomite provides insights into the relative impacts on performance of specific components of the natural barrier system and institutional controls at the WIPP.

The uppermost CCDF in Figure 3, labeled "Total, Single Porosity + Cuttings, Ao" and calculated using the single-porosity (fracture only) and constant $\lambda$ models, represents an estinate of the performance of the disposal system with very little contribution from the natural barrler provided by retardation in the Culebra Dolomite and no contribution from the potential institutional barrier that could be provided by passive markers, as required by the Assurance Requirements (191.14). I For the modeling system and data base used in 1992, the mean CCDF for this case lies below the EPA limits.

The segments of a CCDF shown with a dotted Iine and labeled "Total, Discharge from Borehole + Cuttings, to" display performance with no contribution whatsoever from retardation in the Culebra Dolomite. This CCDF is unlike others shown in this figure in that releases are not calculated at the accessible environment and therefore is not suitable for comparison, preliminary or otherwise, with the Containment Requirements. The curve displays releases directly into the Culebra Dolomite (with cuttings also included) from boreholes occurring at 1000 years and therefore provides an estimate of total releases if subsurface transport to the accessible environment were instantaneous and complete. Instantaneous and complete transport is physically unrealistic, and this curve is displayed only for the purpose of comparison with the curve described in the previous paragraph, which was calculated using the singleporosity and constant $\lambda$ models. The two curves are identical for most of their lengths. The differences between the curves are caused by radioactive decay during transport, and the single-porosity transport model in effect allows all sufficiently long-lived radionuclides that enter the Culebra Dolomite to be transported to the accessible environment within the 9000 years following intrusion.

The CCDF in Figure 3 labeled "Total, Dual Porosity + Cuttings, $K_{d} \sim 0, \lambda_{0}{ }^{n}$ represents an estinate of the performance of the disposal systen if physical retardation by diffusion into the pore volune of the Culebra Dolomite is included as a part of the natural barrier system. The area between the first and second CCDFs is a measure of the potential regulatory impact of including physical retardation. Similarly, the next CCDF in Figure 3, calculated using the dual-porosity, $K_{d}=0$, and constant $\lambda$ models, represents an estimate of the performance of the disposal system if both physical and chemical retardation in the Culebra Dolomite are included in the natural barrier system. The location of this third curve is determined entirely by cut. tings releases. 


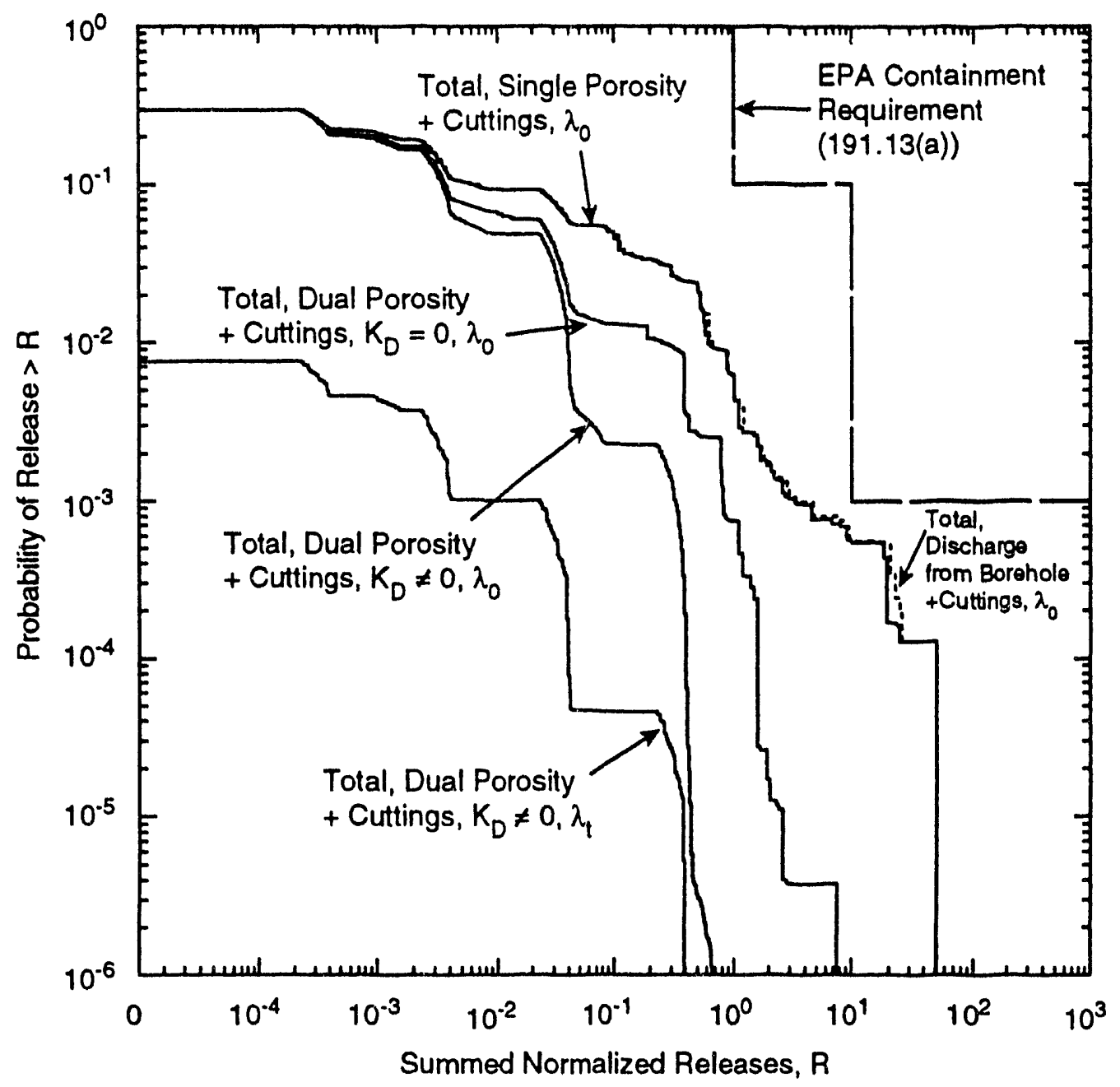

TRI. $2342-23900$ TR1-6342-2397-0 TRI-6342-2410-0 TRI-6342-2411-0 TA1-6342-2414-0

Figure 3 - Comparison of mean CCDFs for total (cuttings plus subsurface) releases from intrusions occurring at 1000 years showing the impact of including specific components of the natural and institutional barrier systems. Both curves shown for $\mathrm{K}_{\mathrm{d}} \neq 0$ are dominated completely by cuttings releases. Summed normalized releases are displayed using an inverse hyperbolic sine scale, which differs from a logarithmic scale only in the interval between 0 and $10^{-4}$. 
The final CCDF in Figure 3, calculated using the dual-porosity, $K_{d}-0$, and time-dependent $\lambda$ models, shows the effect of Including expert judgment on the efficacy of passive markers in reducing the probability of human intrusion. This final CCDF, also determined entirely by cuttings releases, was calculated using what the WIPP PA Department believes at this time to be the most realistic conceptual model for the disposal system, based on models and data available in 1992. As indicated previously, results are preliminary, and none of the curves shown in Figure 3 are belleved sufficlently defensible for use in a final compliance evaluation.

\section{CONCLUSIONS}

Significant improvements in the 1992 PA modeling systew over that used in previous years 26 were the simulation of waste-generated gas and two-phase (brine and gas) flow modeling in the repository; the use of geostatistically generated transmissivity fields in the Culebra Dolomite Member; the use of a Poisson model with time-varying drilling intensities to determine scenario probabilities; the inclusion of a preliminary analysis of potential effects of climate variability on flow in the Culebra Dolomite; and the inclusion of the effects of salt creep (closure and inflation of waste panels) Processes not included in the analyses reported in the set of documents comprising the $1942 \mathrm{PA}$ that could have a significant effect on performance are fracturing in the anhydrite interbeds, and spalling into an intrusion borehole. Important uncertainties that have not been assessed and included in the $1992 \mathrm{PA} 14-16$ are conceptual uncertainties in many parts of the system, both in non-Salado and Salado natural barrier systems and within the engineered barrier system. Effects of subsidence due to potash mining were not included in the scenario analyses. WIPP PA has a high level of confidence that the net effect of including these refinements will not change the overall conclusions (major conclu. sions 1 and 2 below) of the 1992 analys is but will provide additional confirmation for those conclustóns.

Major conclusions that can be drawn from the 1992 preliminary PA for the WIPP are as follows:

1. PA analysts have high confidence that compliance with Subpart B of 40 CFR 191 can be demonstrated.

2. By comparison with doses from other common sources and ICRP recommendations, PA analysts have high confidence that the facility is safe for long-term isolation.

These two conclusions, and therefore demonstration of compliance with 40 CFR 191B and determination of the long-term safety of the disposal system, are conditional on completion of those portions of the WIPP Test Phase Plan27 that are shown to be important for PA, to confirm that reality lies within the range of uncertainty used by PA.

Analyses supporting these conclusions Indicate that, with regard to $40 \mathrm{CFR} 191 \mathrm{~B}$, the direct release of radioactive material at the ground surface during borehole intrusions dominates the estimates of cumulative 10,000-year releases. Important uncertain parameters include the rate of fiture intrusion, the permeability of future borehole fill, and the diameter of future boreholes. An important assumption used in calculating these direct releases is that present-day drilling technology persists for 10,000 years. Other parameters for which uncertainty has a relatively large impact on cumulative radionuclide releases include permeabilities of the anhydrite and halite of the undisturbed Salado Formation, radionuclide solubilities in repository brine, radionuclide retardation in the Culebra Dolomite, and parameters used in the assumed dual-porosity model for radionuclide transport in the Culebra Dolomite.

\section{ACKNOWLEDGMENT}

This is Sandia National Laboratories report SAND93-0054C. Work was performed for the United States Department of Energy under Contract DE-AC04-76DP00789.

\section{REFERENCES}

1. United States Environmental Protection Agency, "40 CFR Part 191: Environmental Standards for the Management and Disposal of Spent Nuclear Fuel, High-Level and Transuranic Radioactive Wastes; Final Rule," Federal Rerister 50. $38066-38089$ (1985).

2. United States Environmental Protection Agency, "40 CFR Part 268: Land Disposal Restrictlons," as amended and published in the most recent Code of Federal Regulations, office of the Federal Register, National Archives and Records Administration, Washington, DC (1986).

3. Public Law 91-190, "National Environmental Policy Act of 1969, as amended by Public Law 94-52 and Public Law 94-83 (1970).

4. United States Department of Energy. "Strategy for the Waste Isolation Pilot Plant Test Phase," DOE $\angle E M / 48063-2$. Office of Waste Operations, US Department of Energy, Washington, DC (1991).

5. Public Law 102-579, "Waste Isolation Pilot Plant Land Withdrawal Act" (1992).

6. United States Department of Energy and State of New Mexico, "Agreenent for Consultation and Cooperation" on the WIPP (1981, modified November 30, 1984; August 4, 1987; and March 22, 1988).

7. S.G. Bertram-Howery, M.G. Marietta, R.P. Rechard, P.N. Swift, D.R. Anderson, B.L. Baker, J.E. Bean, Jr., W. Beyeler, K.F. Brinster, R.V. 
Guzowsk1, J.C. Helton, R.D. McCurley, D.K. Rudeen, J.D. Schrelber, and P. Vaughn, "Preliminary Comparison with 40 CFR Part 191, Subpart B for the Waste Isolation Pilot Plant, December 1990, SAND90-2347. Sandia National Laboratories (1990)

8. R.P. Rechard, H. Iuzzolino, and J.S. Sandha, "Data Used in Preliminary Performance Assessment of the Waste Isolation Pilot: Plant (1990)," SAND89.2408, Sandia National Laboratories (1990).

9. J.C. Helton, J.C., J.W. Garner, R.D. McCurley, and D.K. Rudeen, "Sensitivity Analysis Techniques and Results for Performance Assess. ment at the Waste Isolation Pilot Plant," SAND90-7103, Sandia National Laboratorles (1991).

10. WIPP Performance Assessment Division, "Preliminary Comparison with 40 CFR Part 191, Subpart B for the Waste Isolation Pilot Plant, December 1991-Volume 1: Methodology and Results," SAND91-0893/1. Sandia National Laboratories (1991).

11. WIPP Performance Assessment Division, "Preliminary Comparison with 40 CFR Part 191, Subpart B for the Waste Isolation Pilot Plant, December 1991-Volume 2: Probability and Consequence Modeling," SAND91-0893/2, Sandia National Laboratories (1991).

12. WIPP Performance Assessment Division, "PreIiminary Comparison with 40 CFR Part 191, Subpart B for the Waste Isolation Pilot Plant, December 1991-Volume 3: Reference Data," SAND91-0893/3, Sandia National Laboratories (1991).

13. J.C. Helton, J.W. Garner, R.P. Rechard, D.K. Rudeen, and P.N. Swift, "Preliminary Comparison with $40 \mathrm{CFR}$ Part 191, Subpart $B$ for the Waste Isolation Pilot Plant, December 1991-Volume 4: Uncertainty and Sensitivity Analysis Results, SAND91.0893/4, Sandia National Laboratories (1992).

14. WIPP Performance Assessment Department, "Preliminary Performance Assessment for the Waste Isolation Pilot Plant, December 1992-Volume 1: Third Comparison with 40 CFR 191, Subpart B," SAND92-0700/1, Sandia National Laboratories (1992).

15. WIPP Performance Assessment Department, "Preliminary Performance Assessment for the Waste Isolation Pilot Plant, December 1992-Volume 2: Technical Basis," SAND92-0700/2. Sandia National Laboratories (1992).

16. Sandia WIPP Project, "Preliminary Performance Assessment for the Waste Isolation Pllot Plant, December 1992-Volume 3: Model Parameters," SAND92-0700/3, Sandia National Laboratories (1992).

17. M.G. Marietta, S.G. Bertram-Howery, D.R. Anderson, K. Brinster, R. Guzowski, H.
Iuzzolino, and R.P. Rechard, "Performance Assessment Methodology Denonstration: Methodology Development for Purposes of Evaluating Compliance with EPA 40 CFR Part 191, Subpart B, for the Waste Isolation Pilot Plant," SAND89-2027. Sandia National Laboratories (1989).

18. S.G. Bertran-Howery, M.G. Marletta, D.R. Anderson, K.F. Brinster, L.S. Gomez, R.V. Guzowsk1, and R.P. Rechard, "Draft Forecast of the Final Report for the Comparison to 40 CFR Part 191. Subpart B for the Waste Isolation Pilot Plant," SAND88-1452, Sandia National Laboratories (1989).

19. WIPP Performance Assessment Department, "Long-Term Gas and Brine Migration at the Waste Isolation Pilot Plant: Preliminary Sensitivity Analyses for Post-Closure 40 CFR 268 (RCRA), May 1992," SAND92-1933, Sandia National Laboratories (1992).

20. L.D. Tyler, R.V. Matalucc1, M.A. Molecke, D.E. Munson, E.J. Nowak, and J.C. Stormont, "Summary Report for the WIPP Technology Development Program for Isolation of Radioactive Waste," SAND88-0844, Sandia National Laborato. ries (1988).

21. D.E. Munson, A.F. Fossum, and P.E. Senseny, "Advances in Resolution of Discrepancies Between Predicted and Measured In Situ WIPP Room Closures," SAND88-2948, Sandia National Laboratories (1989).

22. D.E. Munson, A.F. Fossum, and P.E. Senseny, "Approach to First Principles Model Prediction of Measured WIPP In Situ Room Closure in Salt," SAND88-2535, Sandia National Laboratories (1989).

23. C.M. Stone, R.D. Krieg, and Z.E. Beisinger, "SANCHO: A Finite Element Computer Program for the Quasistatic, Large Deformation, Inelastic Response of Two-Dimensional Solids," SAND84-2618, Sandia National Laboratories (1985)

24. A.M. LaVenue and B.S. RamaRao, "A Modeling Approach to Address Spatial Variability within the Culebra Dolomite Transmissivity Field," SAND89-7306, Sandia National Laboratories (1993).

25. P.S. Huyakorn, H.O. White, Jr., and S. Panday, STAFF2D Solute Transport and Fracture Elow in Two Dimensions, Hydrogeologic, Inc., Herndon, VA (1989).

26. M.G. Marietta, S.G. Bertram-Howery, R.P. Rechard, and D.R. Anderson, "Status of WIPP Compllance with EPA 40 CFR 191, December 1990," High Level Radioactive Waste Management, Proceedings of the Second Annual International Conference, Las Veras. Aprif 28-May 3, 1991. 2 . $1181-1188$

27. United States Department of Energy WIPP Project Integration office, "WIPP Test Phase P1an," DOE/NIPP89-011. Rev, 1. Albuquerque, NM (1993). 


\section{DISTRIBUTION}

(Send Distribution list changes to M.M. Gru(bel, Dept. 6342, Sandia

National Laboratories, PO Box 5800, Albuquerque, NM 87185-5800)

\section{Federal Agencies}

US Department of Energy ( 6 )

Office of Civilian Radioactive Waste

Management

Attn: Deputy Director, RW-2

Associate Director, RW-10/50

Office of Program and

Resources Management

Office of Contract Business

Management

Director, RW-22, Analysis and

Verification Division

Associate Director, RW-30

Office of Systems and

Compliance

Associate Director, RW-40

Office of Storage and

Transportation

Director, RW-4/5

Office of Strategic Planning

and International Programs

Office of External Relations

Forrestal Building

Washington, DC 20585

US Department of Energy

Albuquerque Operations office

Attn: National Atomic Museum Library PO Box 5400

Albuquerque, NM 87185

US Department of Energy (2)

Office of Environmental Restoration

and Waste Management

Attn: $\mathrm{EM}-1$

C. Frank, EM-50

Washington, DC 20585

IIS Department of Energy (3)

Office of Environmental Restoration and Waste Management

Attn: M. Frei, EM-34, Trevion II

Director, Waste Management Projects

Washington, DC 20585-0002

US Department of Energy

Office of Environmental Restoration and Waste Management

Attn: J. Lytle, EM-30, Trevion II

Washington, DC 20585-0002
US Department of Energy

Office of Environmental Restoration and Waste Management

Attn: S. Schneider, EM-342, Trevion II

Washington, DC 20585-0002

US Department of Energy (3)

WIPP Task Force

Attn: G.H. Daly

S. Fucigna

B. Bower

12800 Middlebrook Rd., Suite 400

Germantown, MD 20874

US Department of Energy (4)

Office of Environment, Safety and Health

Attn: R.P. Berube, EH-20

C. Borgstrum, EH-25

R. Pelletier, EH-231

K. Taimi, EH-232

Washington, DC 20585

US Department of Energy (6)

WIPP Project Integration Office

Attn: S. Alcorn

W.J. Arthur III

$\mathrm{J}$. Coffey

L.W. Gage

P.J. Higgins

D.A. Olona

PO Box 5400

Albuquerque, NM 87115-5400

US Department of Energy (2)

WIPP Project Integration Satellite

Office

Attn: R. Batra

R. Becker

PO Box 3090, Mail Stop 525

Carlsbad, NM 88221-3090

US Department of Energy (10)

WIPP Project Site Office (Carlsbad)

Attn: A. Hunt (4)

V. Daub (4)

$J$. Lippis

$\mathrm{K}$. Hunter

PO Box 3090

Carlsbad, NM 88221-3090 
US Department of Energy

Research \& Waste Management Division

Attn: Director

PO Box E

Oak Ridge, TN 37831

US Department of Energy

Idaho Operations office

Fuel Processing and Waste

Management Division

785 DOE Place

Idaho Falls, ID 83402

US Department of Energy

Savannah River Operations Office

Defense Waste Processing

Facility Project nffice

Attn: W.D. Pearson

PO Box A

Aiken, SC 29802

US Department of Energy (2)

Richland Operations office

Nuclear Fuel Cycle \& Production Division

Attn: R.E. Gerton

$825 \mathrm{~J}$ adwin Ave.

PO Box 500

Richland, WA 99352

US Department of Energy

Office of Geologic Disposal

Yucca Mountain Project Office

Attn: Associate Director, RW-20

PO Box 98608

Las Vegas, NV 89193-8608

US Department of Energy (3)

Nevada Operations Office

Attn: J.R. Boland

D. Livingston

P.K. Fitzsimmons

2753 S. Highland Drive

Las Vegas, NV 89183-8518

US Department of Energy (2)

Technical Information Center

PO Box 62

Oak Ridge, TN 37831

US Department of Energy

Los Alamos Area Office

52835 th Street

Los Alamos, NM 87544
US Department of Energy (2)

Chicago Operations Office

Attn: J.C. Haugen

9800 South Cass Avenue

Argonne, IL 60439

US Department of Energy (3)

Rocky Flats Area iffice

Attn: W.C. Rask

G. Huffman

T. Lukow

PO Box 928

Golden, CO 80402-0928

US Department of Energy

Dayton Area Office

Attn: R. Grandfield

PO Box 66

Miamisburg, OH 45343-0066

US Department of Energy

Attn: E. Young

Room E-178

GAO/RCED/GTN

Washington, DC 20545

US Bureau of Land Management

Carlsbad office

101 E. Mermod

Carlsbad, NM 88220

US Bureau of Land Management

New Mexico State Office

PO Box 1449

Santa Fe, NM 87507

US Environmental Protection Agency (2)

Radiation Protection Programs

Attn: M. Oge

ANR -460

Washington, DC 20460

US Environmental Protection Agency, Region 6

Attn: C. Byrum, 6T-ET

1445 Ross Ave.

Dallas, TX 75202

US Geological Survey (2)

Water Resources Division

Attn: C. Peters

4501 Indian School NE

Suite 200

Albuquerque, NM 87110 
US Nuclear Regulatory Commission Division of Waste Management

Attn: H. Marson

Mail Stop 4-H-3

Washington, DC 20555

US Nuclear Regulatory Commission (4) Advisory Committee on Nuclear Waste

Attn: D. Moeller

M.J. Steindler

P.W. Pomeroy

W.J. Hinze

7920 Norfolk Ave.

Bethesda, MD 20814

Defense Nuclear Facilities Safety

Board

Attn: D. Winters

625 Indiana Ave. NW

Suite 700

Washington, DC 20004

Nuclear Waste Technical Review Board Attn: Library (2)

1100 Wilson Blvd.

Suite 910

Arlington, VA 22209-2297

Energy and Science Division

Office of Management and Budget

Attn: K. Yuracko

72517 th Street NW

Washington, DC 20503

\section{State Agencies}

New Mexico Bureau of Mines

and Mineral Resources

Socorro, NM 87801

New Mexico Energy, Minerals and

Natural Resources Department

Attn: Librarian

2040 South Pacheco

Santa Fe, NM 87505

New Mexico Energy, Minerals and

Natural Resources Department

New Mexico Radioactive Task Force (2)

(Governor's WIPP Task Force)

Attn: A. Lockwood, Chairman

C. Wentz, Policy Analyst

2040 South Pacheco

Santa Fe, NM 87505
Bob Forrest

Mayor, City of Carlsbad

PO Box 1569

Carlsbad, NM 88221

Carlsbad Department of Development Executive Director

Attn: C. Bernard

PO Box 1090

Carlsbad, NM 88221

New Mexico Environment Department Secretary of the Environment (3)

Attn: J. Espinosa

PO Box 968

1190 St. Francis Drive

Santa Fe, NM 87503-0968

New Mexico Environment Department

Attn: P. McCasland

WIPP Project Site Office

PO Box 3090

Carlsbad, NM 88221-3090

New Mexico State Engineer's Office Attn: M. Chudnoff

PO Box 25102

Santa Fe, NM 87504-51.02

Environmental Evaluation Group (5) Attn: R. Neill

7007 Wyoming Blvd. NE, Suite F-2

Albuquerque, NM 87109

\section{Advisory Committee on Nuclear Facility Safety}

John F. Ahearne

Executive Director, Sigma Xi

99 Alexander Drive

Research Triangle Park, NC 27709

James E. Martin

109 Observatory Road

Ann Arbor, MI 48109

\section{WIPP Panel of National Research Council's Board on Radioactive Waste Management}

Charles Fairhurst, Chairman

Department of Civil and

Mineral Engineering

University of Minnesota

500 Pillsbury Dr. SE

Minneapolis, MN 55455-0220 
John O. Blomeke

3833 Sandy Shore Drive

Lenoir City, TN 37771-9803

John D. Bredehoeft

Western Region Hydrologist

Water Resources Division

US Geological Survey (M/S 439)

345 Middlefield Road

Menlo Park, CA 94025

Rodney C. Ewing

Department of Geology

University of New Mexico

Albuquerque, NM 87131

B. John Garrick

PLG, Inc.

4590 MacArthur Blvd.

Suite 400

Newport Beach, CA 92660-2027

Leonard F. Konikow

US Geological Survey

431 National Center

Reston, VA 22092

Jeremiah O'Driscoll

505 Valley Hill Drive

Atlanta, GA 30350

Chris G. Whipple

ICF Kaiser Engineers

1800 Harrison St.

Oakland, CA 94612-3430

National Research Council (3)

Board on Radioactive Waste Management HA 456

Attn: C.A. Anderson

P.B. Myers

G.J. Grube

2101 Constitution Ave. NW

Washington, DC 20418

\section{Performance Assessment Peer Review Panel}

G. Ross Heath

College of Ocean and Fishery

Sciences, $\mathrm{HN}-15$

583 Henderson Hall

University of Washington

Seattle, WA 98195
Thomas H. Pigford

Department of Nuclear Engineering

4159 Etcheverry Hall

University of California

Berkeley, CA 94720

Thomas A. Cotton

JK Research Associates, Inc.

4429 Butterworth Place NW

Washington, DC 20016

Robert J. Budnitz

President, Future Resources

Associates, Inc.

2000 Center Street, Suite 418

Berkeley, CA 94704

C. John Mann

Department of Geology

245 Natural History Bldg.

1301 West Green Street

University of Illinois

Urbana, IL 61801

Frank W. Schwartz

Department of Geology and Mineralogy

The Ohio State University

Scott Hall

1090 Carmack Rd.

Columbus, $\mathrm{OH} 43210$

\section{National Laboratories}

Argonne National Laboratory (2)

Attn: A. Smith

D. Tomasko

9700 South Cass, Bldg. 201

Argonne, IL 60439

Battelle Pacific Northwest

Laboratory (2)

Attn: S. Bates

R.E. Westerman

MSIN P8-44

Battelle Boulevard

Kichland, WA 99352

Idaho National Engineering

Laboratory (2)

Attn: H. Loo

$R$. Klinger

Mail Stop 5108

Idaho Falls, ID 83403-4000 
Los Atamos National Laboratory (5)

Attn: B. Erdal, INC-12

M. Ennis, HS -12

Mail Stop J 900

S. Kosiewicz, EM-7

Mail Stop J595

L. Soholt, EM-13

Mail Stop M992

J. Wenzel, HS-12

Mail Stop $\mathrm{K} 482$

PO Box 1663

Los Alamos, NM 87545

Oak Ridge National Laboratory

Transuranic Waste Manager

Attn: D.W. Turner

Bldg. 3047

PO Box 2008

Oak Ridge, TN 37831-6060

Pacific Northwest Laboratory

Attn: B. Kennedy

PO Box 999

Richland, WA 99352

Westinghouse-Savannah River

Technology Center (4)

Attn: N. Bibler

J.R. Harbour

M.J. Plodinec

G.G. Wicks

Aiken, SC 29802

\section{Corporations/Members of the Public}

Battelle Memorial Institute

Attn: R. Root

J. Kircher

505 Marquette NW

Suite 1

Albuquerque, NM 87102

Benchmark Environmental Corp.

Attn: C. Frederickson

4501 Indian School NE

Suite 105

Albuquerque, NM 87110

Beta Corporation Int.

Attn: E. Bonano

6613 Esther NE

Albuquerque, NM 87109
City of Albuquerque

Public Works Department

Utility Planning Division

Attn: W.K. Summers

PO Box 1293

Albuquerque, NM 87103

Deuel and Associates, Inc.

Attn: R.W. Prindle

7208 Jefferson NE

Albuquerque, NM 87109

Disposal Safety, Inc.

Attn: B. Ross

1660 L Street NW, Suite 314

Washington, DC 20036

Ecodynamics (2)

Attn: P. Roache

R. Blaine

PO Box 9229

Albuquerque, NM 87119-9229

EG \& G Idaho (3)

1955 Fremont Street

Attn: C. Atwood

C. Hertzler

T.I. Clements

Idaho Falls, ID 83415

Geomatrix

Attn: K. Coppersmith

100 Pine St., Suite 1000

San Francisco, CA 94111

Golder Associates, Inc.

Attn: R. Kossik

4104 148th Avenue NE

Redmond, WA 98052

INTERA, Inc .

Attn: A.M. LaVenue

1650 University Blvd. NE, Suite 300

Albuquerque, NM 87102

INTERA, Inc.

Attn: J.F. Pickens

6850 Austin Center Blvd., Suite 300

Austin, TX 78731

INTERA, Inc.

Attn: W. Stensrud

PO Box 2123

Carlsbad, NM 88221 
INTERA, Inc.

Attn: W. Nelson

101 Convention Center Drive

Suite 540

Las Vegas, NV 89109

IT Corporation (2)

Attn: R.F. Mckinney

J. Myers

Regional office

Suite 700

5301 Central Avenue NE

Albuquerque, NM 87108

John Hart and Associates, P.A.

Attn: J.S. Hart

2815 Candelaria Road NW

Albuquerque, NM 87107

John Hart and Associates, P.A.

Attn: K. Lickliter

1009 North Washington

Tacoma, WA 98406

MAC Technical Services Co.

Attn: D.K. Duncan

8418 Zuni Road SE

Suite 200

Albuquerque, NM 87108

Newman and Holtzinger

Attn: C. Mallon

1615 L Street NW

Suite 1000

Washington, DC 20036

$\mathrm{RE} / \mathrm{SPEC}$, Inc. (2)

Attn: W. Coons

4775 Indian School NE

Suite 300

Albuquerque, NM 87110

$\mathrm{RE} / \mathrm{SPEC}$, Inc.

Attn: J.L. Ratigan

PO Box 725

Rapid City, SD 57709

Reynolds Electric and Engineering Company, Inc.

Attn: E.W. Kenda11

Building 790

Warehouse Row

PO Box 98521

Las Vegas, NV 89193-8521
Science Applications International

Corporation (SAIC)

Attn: H.R. Pratt

10260 Campus Point Drive

San Diego, CA 92121

Science Applications International

Corporation (2)

Attn: D.C.Royer

C.G. Pflum

101 Convention Center Dr.

Las Vegas, NV 89109

Science Applications International

Corporation (3)

Attn: M. Davis

R. Guzowski

$\mathrm{J}$. Tollison

2109 Air Park Road SE

Albuquerque, NM 87106

Science Applications International

Corporation (2)

Attn: J. Young

D. Lester

18706 North Creek Parkway, Suite 110 Bothe11, WA 98011

Southwest Research Institute

Center for Nuclear Waste Regulatory

Analysis (2)

Attn: P.K. Nair

6220 Culebra Road

San Antonio, TX 78228.0510

Systems, Science, and Software (2)

Attn: E. Peterson

Box 1620

P. Lagus

La Jolla, CA 92038

TASC

Attn: S.G. Oston

55 Walkers Brook Drive

Reading, MA 01867

Tech Reps, Inc. (6)

Attn: J. Chapman (2)

C. Crawford

D. Marchand

T. Peterson

J. Stikar

D. Scott

5000 Marble NE, Suite 222

Albuquerque, NM 87110 
Tolan, Beeson \& Associates

Attn: T.L. Tolan

2320 W. 15th Avenue

Kennewick, WA 99337

TRW Environmental Safety Systems (2)

Attn: I. Sacks, Suite 800

L. Wildman, Suite 1300

2650 Park Tower Drive

Vienna, VA 22180-7306

Sanford Cohen and Associates

Attn: J. Channel1

7101 Carriage Rd NE

Albuquerque, NM 87109

Westinghouse Electric Corporation (5)

Attn: Library

C. Cox

L. Fitch

B.A. Howard

R.F. Kehrman

PO Box 2078

Carlsbad, NM 88221

Westinghouse Hanford Company

Attn: D.E. Wood, MSIN HO-32

PO Box 1970

Richland, WA 99352

Western Water Consultants

Attn: P.A. Rechard

PO Box 4128

Laramie, WY 82071

Western Water Consultants

Attn: D. Fritz

1949 Sugarland Drive \#134

Sheridan, WY 82801-5720

P. Drez

8816 Cherry Hills Road NE

Albuquerque, NM 87111

David Lechel

9600 Allende Rd. NE

Albuquerque, NM 87109

C.A. Marchese

PO Box 21790

Albuquerque, NM 87154

Arend Meijer

3821 Anderson SE

Albuquerque, N'M 87108
D.W. Powers

Star Route Box 87

Anthony, TX 79821

Shirley Thieda

PO Box 2109, RR1

Bernalillo, NM 87004

Jack Urich

c/o CARD

144 Harvard SE

Albuquerque, NM 87106

\section{Universities}

University of California

Mechanical, Aerospace, and

Nuclear Engineering Department (2)

Attn: W. Kastenberg

D. Browne

5532 Boelter Hall

Los Angeles, CA 90024

University of California

Engineering and Applied Science Attn:

D. Okrent

48-121A Engineering IV

Los Angeles, CA 90024-1597

University of California

Mine Engineering Department

Rock Mechanics Engineering

Attn: N. Cook

Berkeley, CA 94720

University of Hawaii at Hilo

Business Administration

Attn: S. Hora

Hilo, HI 96720-4091

University of New Mexico

Geology Department

Attn: Library

Albuquerque, NM 87131

University of New Mexico

Research Administration

Attn: H. Schreyer

102 Scholes Hall

Albuquerque, NM 87131

University of Wyoming

Department of Civil Engineering

Attn: V.R. Has further

Laramie, WY 82071 
University of Wyoming

Department of Geology

Attn: J.I. Drever

Laramie, WY 82071

University of Wyoming

Department of Mathematics

Attn: R.E. Ewing

Laramie, WY 82071

\section{Libraries}

Thomas Brannigan Library

Attn: D. Dresp

$106 \mathrm{~W}$. Hadley St.

Las Cruces, NM 88001

New Mexico State Library

Attn: N. McCallan

325 Don Gaspar

Santa Fe, NM 87503

New Mexico Tech

Martin Speere Memorial Library

Campus Street

Socorro, NM 87810

New Mexico Junior College

Pannell Library

Attn: R. Hill

Lovington Highway

Hobbs, NM 88240

Carlsbad Municipal Library

WIPP Public Reading Room

Attn: L. Hubbard

$101 \mathrm{~S}$. Halagueno St.

Carlsbad, NM 88220

University of New Mexico

Zimmerman Library

Government Publications Department

Albuquerque, NM 87131

\section{NEA/Performance Assessment Advisory Group (PAAG)}

P. Duerden

ANSTO

Lucas Heights Research Laboratories

Private Mail Bag No. 1

Menai, NSW 2234

AUSTRALIA
Gordon S. Linsley

Division of Nuclear Fuel Cycle and

Waste Management

International Atomic Energy Agency

PO Box 100

A-1400 Vienna, AUSTRIA

Nicolo Cadelli

Commission of the European

Communities

200, Rue de la Loi

B-1049 Brussels, BELGIUM

R. Heremans

Organisme Nationale des Déchets

Radioactifs et des Matiéres Fissiles (ONDRAF)

Place Madou 1, Boitec 24/25

B-1030 Brussels, BELGIUM

J. Marivoet

Centre d'Etudes de l'Energie

Nucléaire (CEN/SCK)

Boeretang 200

B-2400 Mo1, BELGIUM

P. Conlon

Waste Management Division

Atomic Energy Control Board (AECB)

PO Box 1046

Ottawa, Ontario KIP 559, CANADA

A.G. Wikjord

Manager, Environmental and Safety Assessment Branch

Atomic Energy of Canada Limited

Whiteshell Research Establishment

Pinewa, Manitoba ROE 1 LO

CANADA

Teollisuuden Voima Oy (TVO) (2)

Attn: Timo Äikäs

Jukka-Pekka Salo

Annankatu $42 \mathrm{C}$

SF-00100 Helsinki Suomi

FINLAND

Timo Vieno

Technical Research Centre of Finland

(VTT)

Nuclear Energy Laboratory

PO Box 208

SF-02151 Espoo, FINLAND 
Division de la Sécurité et de la Protection de l'Environment (DSPE) Commissariat á l'Energie Atomique Agence Nationale pour la Gestion des Déchets Radioactifs (ANDRA)

Attn: Gérald Ouzounian

M. Claude Ringeard

Route du Panorama Robert Schuman

B. P. No. 38

F-92266 Fontenay-aux-Roses Cedex FRANCE

Claudio Pescatore

Division of Radiation Protection and Waste Management

OECD Nuclear Energy Agency

38, Boulevard Suchet

F-75016 Paris, FRANCE

M. Dominique Greneche

Commissariat á l'Energie Atomique IPSN/DAS/SASICC/SAED

B.P. No. 6

F-92265 Fontenay-aux-Roses Cedex FRANCE

Robert Fabriol

Bureau de Recherches Géologiques et Miniéres (BRGM)

B.P. 6009

45060 Orléans Cedex 2, FRANCE

P. Bogorinski

Gesellschaft für Reaktorsicherheit (GRS) $\mathrm{MBH}$

Schwertnergasse 1

D-5000 Köln 1, GERMANY

R. Storck

GSF - Institut für Tieflagerung

Theodor-Heuss-Strabe 4

D-3300 Braunschweig, GERMANY

Ferrucio Gera

ISMES S.P.A

Via del Crociferi 44

I-00187 Rome, ITALY

Hiroyuki Umeki

Isolation System Research Program

Radioactive Waste Management Project

Power Reactor and Nuclear Fuel

Development Corporation (PNC)

1-9-13, Akasaka, Minato-ku

Tokyo 107, JAPAN
Tönis Papp

Swedish Nuclear Fuel and Waste

Management Co.

Box 5864

S 10248 Stockholm

SWEDEN

Conny Hägg

Swedish Radiation Protection

Institute (SSI)

Box 60204

S-104 01 Stockholm

SWEDEN

J . Hadermann

Paul Scherrer Institute

Waste Management Programme

$\mathrm{CH}-5232$ Villigen PSI

SWITZERLAND

$\mathrm{J}$. Vigfusson

HSK-Swiss Nuclear Safety Inspectorate

Federal Office of Energy

CH-5232 Villigen-HSK

SWITZERLAND

D.E. Billington

Departmental Manager-Assessment Studies

Radwaste Disposa1 R\&D Division

AEA Decommissioning \& Radwaste

Harwell Laboratory, B60

Didcot Oxfordshire OX11 ORA

UNITED KINGDOM

P. Grimwood

Waste Management Unit

BNFL

Sellafield

Seascale, Cumbria CA20 1PG

UNITED KINGDOM

Alan J. Hooper

UK Nirex Ltd

Curie Avenue

Harwe 11, Didcot

Oxfordshire, OX11 ORH

UNITED KINGDOM

Jerry M. Boak

Yucca Mountain Project office

US Department of Energy

PO Box 98608

Las Vegas, NV 89193 
Seth M. Coplan (Chairman)

US Nuclear Regulatory Commission

Division of High-Level Waste

Management

Mail Stop 4-H-3

Washington, DC 20555

\section{A.E. Van Luik}

INTERA/M\&O

The Valley Bank Center

101 Convention Center Dr.

Las Vegas, NV 89109

\section{NEA/Prohabilistic System Assessment Group (PSAG)}

Shaheed Hossain

Division of Nuclear Fuel Cycle and Waste Management

International Atomic Energy Agency Wagramerstrasse 5

PO Box 100

A.1400 Vienna, AUSTRIA

Alexander Nies (PSAC Chairman)

Gesellschaft für Strahlen- und

Institut für Tieflagerung

Abteilung für Endlagersicherheit

Theodor-Heuss-Strasse 4

D-3300 Braunschweig

GERMANY

Eduard Hofer

Gesellschaft für Reaktorsicherheit (GRS) MBH

Forschungsgelände

D-8046 Garching, GERMANY

Andrea Saltelli

Commission of the European

Communities

Joint Resarch Centre of Ispra

I-21020 Ispra (Varese)

ITALY

Alejandro Alonso

Cátedra de Tecnología Nuclear

E.T.S. de Ingenieros Industriales

José Gutiérrez Abascal, 2

E-28006 Madrid, SPAIN

ENRESA (2)

Attn: M. A. Cuñado

F. J. Elorza

Calle Emilio Vargas, 7

E-28043 Madrid, SPAIN
Pedro Prado

CIEMAT

Instituto de Tecnologia Nuclear

Avenida Complutense, 22

E-28040 Madrid, SPAIN

Nils A. Kjellbert

Swedish Nuclear Fuel and Waste

Management Company (SKB)

Box 5864

S-102 48 Stockholm, SWEDEN

Björn Cronhjort

Royal Institute of Technology

Automatic Control

S-100 44 Stockholm, SWEDEN

Richard A. Klos

Paul-Scherrer Institute (PSI)

CH-5232 Villingen PSI, SWITZERLAND

Nationale Genossenschaft für die

Lagerung Radioaktiver Abfälle (2)

Attn: C. McCombie

F. Van Dorp

Hardstrasse 73

$\mathrm{CH}-5430$ Wettingen, SWITZERLAND

N. A. Chapman

Intera Information Technologies

Park View House

14B Burton Street

Melton Mowbray

Leicestershire LE13 1AE

UNITED KINGDOM

Daniel A. Galson

Galson Sciences Ltd.

35, Market Place

Oakham

Leicestershire LE15 6DT

UNITED KINGDOM

David P. Hodgkinson

Intera Information Technologies

45 Station Road, Chiltern House

Henley-on-Thames

Oxfordshire RG9 1AT

UNITED KINGDOM

Brian G.J. Thompson

Department of the Environment: Her Majesty's Inspectorate of Pollution Room A5.33, Romney House

43 Marsham Street

London SW1P 2PY, UNITED KINGDOM 
Intera Information Technologies

Attn: M.J.Apted

3609 South Wadsworth Blvd.

Denver, CO 80235

US Nuclear Regulatory Commission (2)

Attn: R. Codell

N. Eisenberg

Mail Stop 4-H-3

Washington, DC 20555

Battelle Pacific Northwest

Laboratories

Attn: P.W. Eslinger

MS K2-32

PO Box 999

Richland, WA 99352

Center for Nuclear Waste Regulatory Analysis (CNWRA)

Southwest Research Institute

Attn: B. Sagar

PO Drawer 28510

6220 Culebra Road

San Antonio, TX 78284

Geostatistics Expert Working Group (GXG)

Rafael L. Bras

R. L. Bras Consulting Engineers

44 Percy Road

Lexington, MA 02173

Jesus Carrera

Universidad Politécnica de Cataluña

E.T.S.I. Caminos

Jordi, Girona 31

E-08034 Barcelona

SPAIN

Gedeon Dagan

Department of Fluid Mechanics and

Heat Transfer

Tel Aviv University

PO Box 39040

Ramat Aviv, Tel Aviv 69978

ISRAEL

Ghislain de Marsily (GXG Chairman)

University Pierre et Marie Curie

Laboratorie de Geologie Applique

4, Place Jussieu

T.26 - $5 \mathrm{e}$ etage

75252 Paris Cedex 05

FRANCE
Alain Galli

Centre de Geostatistique

Ecole des Mines de Paris

35 Rue St. Honore

77035 Fontainebleau, FRANCE

Christian Ravenne

Geology and Geochemistry Division

Institut Francais du Pétrole

$1 \& 4$, Av. de Bois-Préau B.P. 311

92506 Rueil Malmaison Cedex

FRANCE

Peter Grindrod

INTERA Information Technologies Ltd.

Chiltern House

45 Station Road

Henley-on-Thames

Oxfordshire, RG9 1AT, UNITED KINGDOM

Alan Gutjahr

Department of Mathematics

New Mexico Institute of Mining and

Technology

Socorro, NM 87801

C. Peter Jackson

Harwell Laboratory

Theoretical Studies Department

Radwaste Disposal Division

Bldg. 424.4

Oxfordshire Didcot Oxon OXI1 ORA

UNITED KINDGOM

Rae Mackay

Department of Civil Engineering

University of Newcastle Upon Tyne

Newcastle Upon Tyne NE1 7RU

UNITED KINGDOM

Steve Gorelick

Department of Applied Earth Sciences

Stanford University

Stanford, CA 94305-2225

Peter Kitanidis

60 Peter Coutts Circle

Stanford, CA 94305

Dennis McLaugh1in

Parsons Laboratory

Room 48-209

Department of Civil Engineering

Massachusetts Institute of Technology

Cambridge, MA 02139 
Shlomo P. Neuman

College of Engineering and Mines Department of Hydrology and Water Resources

University of Arizona

Tucson, AZ 85721

Yoram Rubin

Department of Civil Engineering

University of California

Berkeley, CA 94720

\section{Foreign Addresses}

Studiecentrum Voor Kernenergie

Centre D'Energie Nucleaire

Attn: A. Bonne

SCK/CEN

Boeretang 200

B- $2400 \mathrm{Mol}$

BELGIUM

Atomic Energy of Canada, Ltd. (3)

Whiteshe11 Research Establishment

Attn: M.E. Stevens

B.W. Goodwin

D. Wushke

Pinewa, Manitoba ROE 1LO, CANADA

Juhani Vira

Teollisuuden Voima Oy (TVO)

Annankatu $42 \mathrm{C}$

SF-00100 Helsinki Suomi

FINLAND

Jean-Pierre Olivier

OECD Nuclear Energy Agency (2)

38, Boulevard Suchet

F-75016 Paris

FRANCE

D. Alexandre, Deputy Director

ANDRA

31 Rue de la Federation

75015 Paris

FRANCE

Claude Sombret

Centre D'Etudes Nucleaires

De La Vallee Rhone

CEN/VALRHO

S.D.H.A. B.P. 171

30205 Bagnols-Sur-Ceze, FRANCE
Bundesministerium fur Forschung und Technologie

Postfach 200706

5300 Bonn 2, GERMANY

Bundesanstalt fur Geowissenschaften und Rohstoffe

Attn: M. Langer

Postfach 510153

3000 Hanover 51, GERMANY

Gesellschaft fur Reaktorsicherheit (GRS) (2)

Attn: B. Baltes

W. Muller

Schwertnergasse 1

D-5000 Cologne, GERMANY

Institut fur Tieflagerung (2)

Attn: K. Kuhn

Theodor-Heuss-Strasse 4

D-3300 Braunschweig, GERMANY

Physikalisch-Technische Bundesanstalt

Attn: P. Brenneke

Postfach 3345

D-3300 Braunschweig, GERMANY

Shingo Tashiro

Japan Atomic Energy Research

Institute

Tokai-Mura, Ibaraki-Ken

319-11, JAPAN

Netherlands Energy Research

Foundation (ECN)

Attn: L.H. Vons

3 Westerduinweg

PO Box 1

1755 ZG Petten, THE NETHERLANDS

Johan Andersson

Swedish Nuclear Power Inspectorate

Statens Kärnkraftinspektion (SKI)

Box 27106

S-102 52 Stockholm, SWEDEN

Fred Karlsson

Svensk Kärnbränsleforsorjning $A B$

Project KBS

Box 5864

S-102 48 Stockholm, SWEDEN 


\author{
Nationale Genossenschaft für die \\ Lagerung Radioaktiver Abfalle (2) \\ Attn: S. Vomvoris \\ P. Zuidema \\ Hardstrasse 73 \\ $\mathrm{CH}-5430$ Wettingen, SWITZERIAND \\ AEA Technology \\ Attn: J.H. Rees \\ D5W/29 Culham Laboratory \\ Abington \\ Oxfordshire OX14 3DB, UNITED KINGDOM \\ AEA Technology \\ Attn: W.R. Rodwell \\ 044/A31 Winfrith Technical Centre \\ Dorchester \\ Dorset DT2 8DH, UNITED KINGDOM \\ AEA Technology \\ Attn: J.E. Tinson \\ B4244 Harwell Laboratory \\ Didcot, Oxfordshire OXI1 ORA \\ UNITED KINGDOM \\ D.R. Knowles \\ British Nuclear Fuels, plc \\ Risley, Warrington \\ Cheshire WA3 6AS, 1002607 \\ UNITED KINGDOM
}

\section{Internal}

$\begin{array}{ll}1 & \text { A. Narath } \\ 20 & \text { O.E. Jones } \\ 1502 & \text { J.C. Cummings } \\ 1511 & \text { D.K. Gartling } \\ 4511 & \text { D.P. Garber } \\ 6000 & \text { D.L. Hartley } \\ 6115 & \text { P.B. Davies } \\ 6115 & \text { R.L. Beauheim } \\ 6119 & \text { E.D. Gorham } \\ 6119 & \text { Staff (14) } \\ 6121 & \text { J.R. Tillerson } \\ 6121 & \text { Staff (7) } \\ 6233 & \text { J.C. Eichelberger } \\ 6300 & \text { D.E. El1is } \\ 6302 & \text { L.E. Shephard } \\ 6303 & \text { S.Y. Pickering } \\ 6303 & \text { W.D. Weart } \\ 6305 & \text { S.A. Goldstein } \\ 6305 & \text { A.R. Lappin }\end{array}$

6306

6312

6313

6331

6341

6342

6342

6343

6343

6345

6345

6347

6348

6348

6351

6352

6400

6613

6613

6613

6622

6641

7141

7151

7613-2 Document Processing for DOE/OSTI (10)

8523-2 Central Technical Files

A.L. Stevens

F.W. Bingham

L.S . Costin

P.A. Davis

D.R. Anderson

Staff (30)

V. Harper-Slaboszewicz

Staff (3)

R.C. Lincoln

Staff (9)

D.R. Schafer

J.T. Holmes

Staff (4)

R.E. Thompson

S.E. Sharpton

N.R. Ortiz

R.M. Cranwell

R.L. Iman

C. Leigh

M.S.Y. Chu

R.E. Luna, Acting

Technical Library (5)

Technical Publications
Sandia WIPP Central Files (100) 

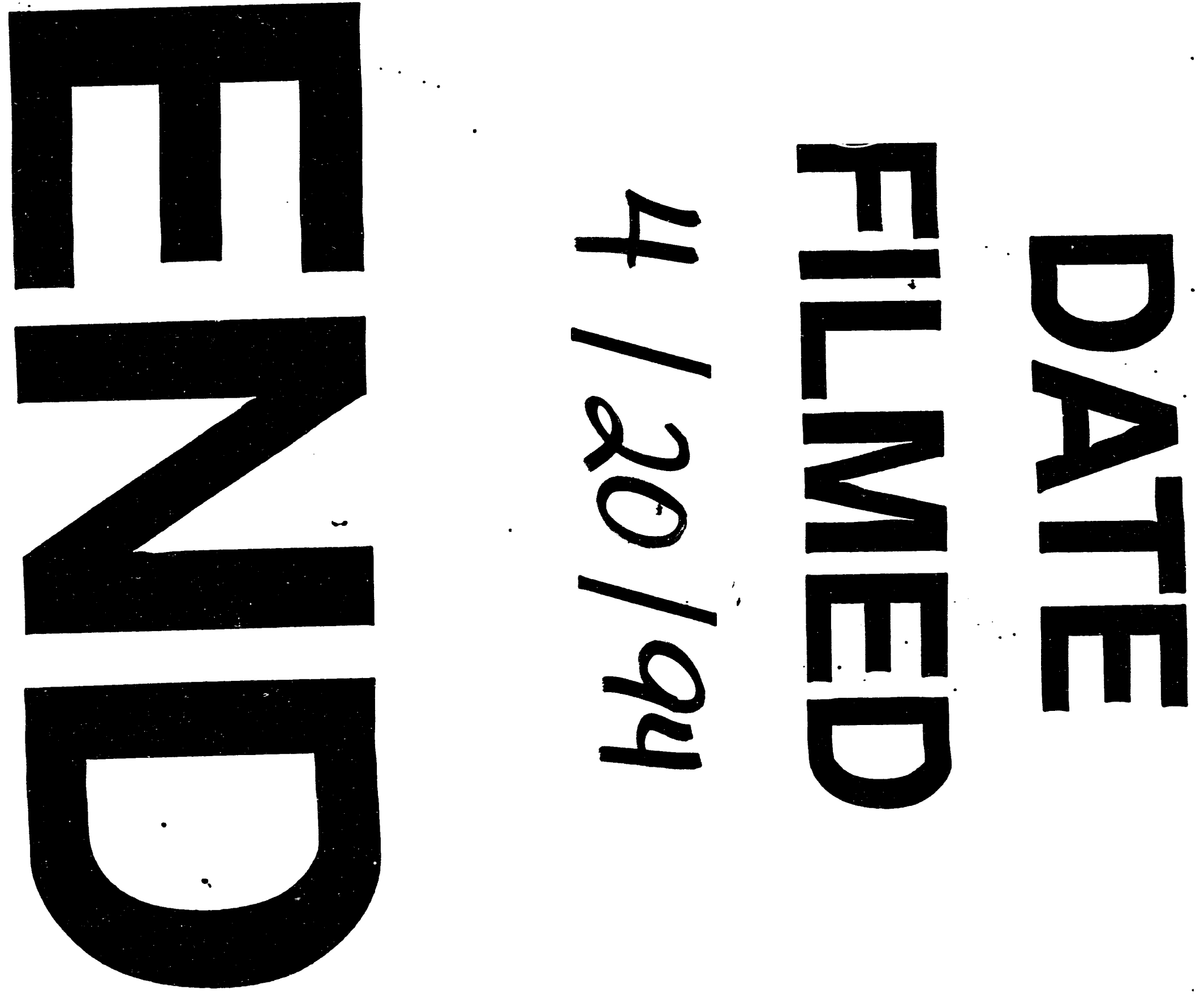
